\title{
PROTECTION OF ECONOMIC COMPETITION: AN OVERVIEW OF THE LATEST LEGISLATIVE NOVELTIES
}

Purpose. The article is dedicated to the analysis of the main changes introduced by the Law of Ukraine "On Amendments to Some Laws of Ukraine ensuring the principles of procedural justice and increasing the efficiency of proceedings in cases of violations of the legislation on the protection of economic competition".

Methods. Law of Ukraine "On Amendments to Some Laws of Ukraine ensuring the principles of procedural justice and increasing the efficiency of proceedings in cases of violations of the legislation on the protection of economic competition" proposes the implementation of several novelties. Among them are: the restriction for the Antimonopoly Committee of Ukraine by certain time limits for considering cases; possibility of extension of the term for consideration of cases by decision of the Committee's State Commissioner or head of a territorial office; renewal of deadlines for consideration of cases where the respondent is replaced or a co-respondent is involved; provision for the consequences of missing the deadlines for considering cases and also the mechanism of consultations during the consideration of a case, which may be appointed either on the initiative of the Antimonopoly Committee of Ukraine or on the motion of interested persons.

Results. The abovementioned amendments will influence the existing system of economic competition protection in a serious way. Among the changes are:

- the fine for delayed payment of a fine imposed by the Antimonopoly Committees of Ukraine decision on violation of the legislation on the protection of economic competition is cancelled; - the member of the Antimonopoly Committee of Ukraine who conducted or organized an investigation is deprived of the right to vote in the process of decision-making in the respective case;

- the procedure for holding hearings is defined;

- recusals and self-recusals are envisaged for the Antimonopoly Committee of Ukraine officers;

- the grounds for acquiring the third-party status in a case are changed;

- the rights of persons involved in the case are specified and expanded.

An important remark of the Law of Ukraine "On Amendments to Some Laws of Ukraine ensuring the principles of procedural justice and increasing the efficiency of proceedings in cases of violations of the legislation on the protection of economic competition" is that a person that is exempted from liability or whose fine is reduced shall still be liable for damage caused by the violation to other persons.

Conclusions. As a result, Law of Ukraine "On Amendments to Some Laws of Ukraine ensuring the principles of procedural justice and increasing the efficiency of proceedings in cases of violations of the legislation on the protection of economic competition" is expected to become an important step forward in increasing the effectiveness of investigations into violations of the legislation on the protection of economic competition. It can also be regarded as the next step to harmonize Ukrainian legislation with the European Union acquis.

Key words: competition, novelties, Antimonopoly Committee of Ukraine, case review, penalties, protection of economic competition. 


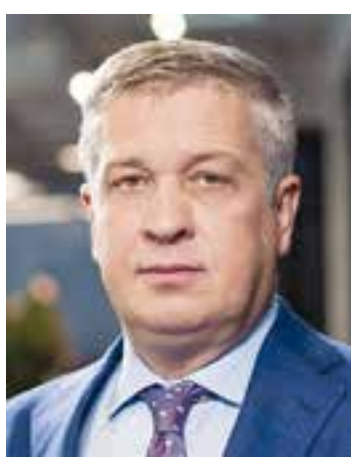

Sergii Shkliar, Partner at Arzinger, Head of Antitrust Practice, LL.D.

Shkliar@arzinger.ua

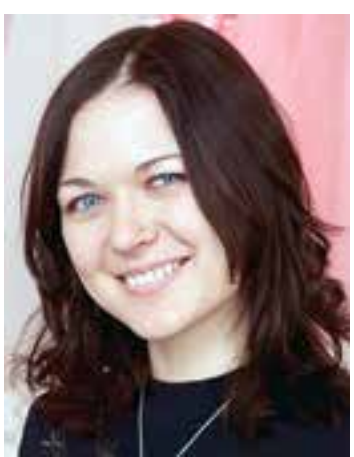

Olha Bulaieva,

Senior Associate at Arzinger orcid.org/0000-0002-1872-0570 Olha.Bulaieva@arzinger.ua

\section{Introduction}

On 7 February 2019, the Parliament adopted the Law of Ukraine "On Amendments to Some Laws of Ukraine ensuring the principles of procedural justice and increasing the efficiency of proceedings in cases of violations of the legislation on the protection of economic competition" (hereinafter - the Law) to amend the Laws of Ukraine "On Protection of Economic Competition" and "On the Antimonopoly Committee of Ukraine".

The final version of the Law has not been published yet (as of imprimatur date $-\mathrm{S}$. Sh., O. B.). The Law will come into effect 3 months after its promulgation (except for the settlement procedure provisions). The changes introduced by the Law are intended to improve the proceedings in cases of competition violation. This can be regarded as the next step to harmonize Ukrainian legislation with the European Union acquis.

In this article, we will analyse the main changes that will soon take place in the Ukrainian legislation on the protection of economic competition.

\section{Timing}

Under the amended Law of Ukraine "On Protection of Economic Competition" the Antimonopoly Committee of Ukraine (hereinafter - AMCU) will be restricted by certain time limits for considering cases, which will be figured from the date of the order on commencement of proceedings till the date of decision-making:

- general term (2 years) - for all violations other than those subject to the special term mentioned below;

- special term (5 years) - for cases of horizontal anti-competitive concerted actions (among competitors);

- special term (1 year) - for cases of violations under the Law of Ukraine "On Protection from Unfair Competition" as well as for cases on breach of provisions of founding documents approved by the AMCU for companies established by merger and for mergers without obtaining the respective clearance from the AMCU;

- special term (6 months) - for cases instituted upon non-compliance with the AMCU's decision; non-provision or provision of incomplete or unreliable information to the AMCU; creating obstacles for the AMCU's officers.

The mentioned terms will be applied to cases instituted by the AMCU's offices after the entry into force of the Law.

The Law provides for the possibility to extend the term for consideration of cases by decision of the Committee's State 
Commissioner or head of a territorial office, however, not more than by 6 months, provided that the following grounds exist: there is a need for obtaining information that was not provided when requested by the Antimonopoly Committee; in case of a hearing; to ensure that the persons involved in the case have enough time to provide their comments on the findings set forth in the Submission with the preliminary findings.

Also, the Law provides for renewal of deadlines for consideration of cases where the respondent is replaced or a co-respondent is involved. It is established that the deadlines for consideration of cases do not include the time for receipt of case-related information requested from the respondent by the Antimonopoly Committee of Ukraine as well as the time of suspension of proceedings on the Committee's initiative for the period of expert examination ordered by the Committee, until the consideration of another related case is completed by the court or until a state authority decides an issue related thereto.

In our opinion, the above rules allow the AMCU to drag out cases. The use of the set of opportunities provided by the Law for extending the term may lead to substantial delays in the actual term provided to the Committee by the Law.

For comparison, we studied the actual timing for the AMCU to handle cases depending on their category. According to the new Law, the deadline for considering an abuse of monopoly case will be 2 years (without taking into account the deadlines for demanding evidence, stay of proceedings etc.). The actual period currently ranges from 4 to 25 months, making up 1 year and 3 months on average. Anti-competitive concerted actions are considered within 1 to 3 months (bid-rigging) to 6 years (cases in the pharmaceutical market), the average period for investigating cases in this category being 2 years, which is much less than the 5 -year term established by the Law. Cases of mergers without obtaining the necessary clearance, for which the Law establishes an annual period, actually last from 2 to 18 months, i. e. 9 months on average. Unfair competition should also be investigated within 1 year, while actual investigations into such cases last from 4 months to 6.5 years, which makes 2.5 years on average. Cases, for which a 6-month period is currently established, are actually investigated within 6 months (non-submission of information), 7 months (incomplete submission of information or unreliable information), or 9 months (creating obstacles for the AMCU's officers).

Apart from that, the Law provides for the consequences of missing the deadlines for considering cases. If the AMCU has not passed a decision within the deadlines set by the Law, the case shall be closed due to failure to prove the violation. In view of the above, the question arises as to the respondent's further actions if the AMCU misses the deadline for considering its case. In our opinion, the respondent should apply the following algorithm to prompt the AMCU to close the case:

- step 1 - ask the AMCU in writing about the reasons for missing the deadline;

- step 2 - unless the AMCU provides a proper justification to the effect that the deadline has not been missed, it is necessary to submit objections to the AMCU's actions with a request to close the proceedings;

- step 3 - if the AMCU does not comply with the respondent's request, a claim should be filed with the administrative court for recognizing the Committee's inaction as unlawful and obliging it to close the case due to failure to prove the violation. 
The problematic point of implementing this mechanism is that the respondent has the right to familiarize itself with the case file only after a submission with preliminary findings is made. Therefore, if the question arises regarding the AMCU's having missed the deadline for considering a case, it will be difficult for the respondent to justify such omission due to the lack of information on the circumstances determining the extension of time limits in a particular case. We believe that the source of such data may be the respondent's exercising the right to ask questions and have them reasonably answered by the Committee, as provided by the new Law.

The problem of further action will also arise before the respondent, if the AMCU makes a decision with omission of the deadline set by the Law. One of the possible algorithms of acting in this case may be to appeal the illegal actions of the Antimonopoly Committee to the administrative court with the simultaneous commitment of the Antimonopoly Committee to act (to review the decision, to close the case). Another option is to appeal the AMCU's decision to the commercial court to invalidated it in connection with a violation of procedural law rules, which has resulted in a wrong decision. The second option is more risky, as it may be difficult to prove to the court that the causal link exists and that the decision is wrong.

\section{Institute of consultations}

One of the novelties under the Law is the stipulated mechanism of consultations during the consideration of a case, which may be appointed either on the AMCU's initiative or on the motion of interested persons. At the same time, the legislation does not specify the persons who may have the status of interested ones. It can be assumed that the consultations may initiated by the persons involved in the case (according to the changes introduced by the Law, such persons include the respondent, the applicant, and a third party) and other interested persons (hypothetical, they may include the participants (shareholders) of persons involved in the case as well as the respondent's officials or officers who allegedly have participated in the violation and are participants in related criminal proceedings, as well as law enforcement (state) authorities investigating related cases).

The purpose of the consultations may be to discuss the actual, economic and legal issues pertaining to the suspected violation, its nature as well as the possibility of voluntary termination or correction of actions that have or may have signs of violation of the legislation on the protection of economic competition.

It can be assumed that the consultation mechanism will be predominantly used by respondents to obtain another platform (apart from hearings) for the AMCU to report its position on the actual facts of the case, to interpret them from the legal or economic standpoint, and to converse with the AMCU on the algorithm and the procedure for the respondent to eliminate the violation.

\section{Settlement with the AMCU}

A settlement procedure may be initiated in a case on the basis of a respondent's statement, which should be filed before the Committee makes its submission with preliminary findings in the case. The settlement procedure is only commenced if the Committee decides that applying that procedure and granting the corresponding consent to the respondent's statement is reasonable. 
At the stage of settlement, the Committee and the respondent conduct negotiations, upon which a settlement agreement may be signed, which should contain the essential conditions specified by the Law (in particular, the legal qualification of the violation, the respondent's acknowledgment of the violation, the circumstances of the violation, the amount of the fine). The fine for such a respondent shall be reduced by $20 \%$ of the amount calculated in accordance with the AMCU's published approaches to the determination of the amount of fines. Such approaches are currently enshrined in the AMCU's Recommendatory Explanations № 39-p dated 09.08.2016.

After the agreement is signed by the parties, it is sent to the commercial court, which approves it, if it contains all the essential conditions stipulated by the Law, or refuses to do so, if the terms of the agreement are contrary to the requirements of the Law, the interests of the State or society, violate the rights and interests of the parties or other persons, or if the respondent is obviously unable to fulfil its obligations.

After the agreement is approved by the court, the Committee makes its decision in the case according to the terms of the settlement agreement, which cannot be further appealed to the court by the respondent. The settlement procedure shall be terminated by the AMCU, if no agreement was reached with the respondent on the essential terms of the agreement, if the respondent did not send the signed agreement to AMCU, or if the commercial court has not approved the terms of the agreement.

If the respondent fails to comply with the requirements of the agreement, the AMCU shall initiate the cancellation of the approval decision and shall review its decision regarding the respondent. It should be recalled that, in reviewing its decision, the Committee may change or cancel the decision or adopt a new one.

However, the mentioned novelties regarding the settlement agreement will turn into "dead" rules, if no relevant changes are introduced to the Commercial Procedural Code next year, which should stipulate the procedure for the court to approve settlement agreements.

\section{Improvement of leniency in cases of anticompetitive concerted actions}

An important and progressive novelty of the Law is the clear and improved (compared to similar provisions of the current Law on the Protection of Economic Competition) algorithm for exempting persons from liability under the so-called leniency program, which is successfully applied to fight cartels in the European Union and the United States.

The law stipulates that a person involved in anticompetitive concerted actions shall not be brought to liability, if it has previously informed the AMCU of the committed anticompetitive concerted actions prior to others. Also, a particular list of conditions is defined, under which a person shall be exempted from liability:

- the statement should be received by the AMCU prior to the commencement of proceedings in the case and before other participants in the concerted actions file their statements;

- the applicant did not initiate the concerted actions;

- the person has terminated the violation;

- the person facilitated the investigation as determined by the law.

For other participants of concerted actions, who have voluntarily applied to the AMCU and provided strong evidence of the violation before they received the submission with 
preliminary findings, the amount of the fine shall be reduced depending on the precedence of providing evidence:

- for the first person - by $50 \%$;

- for the second person - by $30 \%$;

- for other persons - by $20 \%$ from the calculated amounts of fines, in accordance with the AMCU's published approaches to determining the amounts of fines.

An important remark of the Law is that a person that is exempted from liability or whose fine is reduced shall still be liable for damage caused by the violation to other persons. It should be recalled that the Law of Ukraine "On Protection of Economic Competition" stipulates that damage may be recovered in a double amount, if it is caused by a competition violation.

6. Other important novelties under the Law

- the fine for delayed payment of a fine imposed by the AMCU's decision on violation of the legislation on the protection of economic competition is cancelled;

- the AMCU's member who conducted or organized an investigation is deprived of the right to vote in the process of decision-making in the respective case;

- the procedure for holding hearings is defined;

- recusals and self-recusals are envisaged for the AMCU's officers;

- the grounds for acquiring the third-party status in a case are changed;

- the rights of persons involved in the case are specified and expanded.

We believe that the adopted Law is an important step forward in increasing the effectiveness of investigations into violations of the legislation on the protection of economic competition. However, Bill № 2431 aimed at improving the process of determining the amount of fines for violations of the legislation on the protection of economic competition was unfortunately not passed into law. In particular, the Bill was supposed to entitle the court to verify the fines calculated by the AMCU and to oblige the AMCU to review its decisions regarding them. At present, the protection of rights in court proceedings is not effective enough, since the court has no authority to influence the amounts of fines, if the latter are found to be not commensurate to the committed violation, in the absence of grounds for invalidating the AMCU's decision.

\section{Conclusions}

As a result, Law of Ukraine "On Amendments to Some Laws of Ukraine ensuring the principles of procedural justice and increasing the efficiency of proceedings in cases of violations of the legislation on the protection of economic competition" is expected to become an important step forward in increasing the effectiveness of investigations into violations of the legislation on the protection of economic competition. It can also be regarded as the next step to harmonize Ukrainian legislation with the European Union acquis. 


\title{
ЗАХИСТ ЕКОНОМІЧНОЇ КОНКУРЕНЦІЇ: ОГЛЯД ОСТАННІХ ЗАКОНОДАВЧИХ НОВЕЛ
}

\author{
Сергій Шкляр, \\ партнер Arzinger, \\ доктор юридичних наук \\ Shkliar@arzinger.ua \\ Ольга Булаєва, \\ старший юрист Arzinger \\ orcid.org/0000-0002-1872-0570 \\ Olha.Bulaieva@arzinger.ua
}

керівник практики антимонопольного права,

Мета. Статтю присвячено аналізу основних змін, внесених Законом Украӥни «Про внесення змін до деяких законів Украӥни щзодо забезпечення принщипів прочесуальної справедливості та підвищення ефективності проваджень у справах про порушення законодавства про захист економічної конкурениї̈».

Методи. Закон України «Про внесення змін до деяких законів України щзодо забезпечення принципів процесуальної справедливості та підвищення ефективності проваджень у справах про порушення законодавства про захист економічної конкурениії» пропонує реалізували декілька новел: обмежити діяльність Антимонопольного комітету України певними строками для розгляду справ; надати можливість продовження строку для розгляду справ за ріменням державного уповноваженого Комітету або голови територіального відділення; надати можливість поновлення термінів розгляду справ, де відбувається заміна відповідача або залучення співвідповідача; ввести покарання за порушення термінів розгляду справ, а також механізм консультаиій під час розгляду справи, які можуть бути призначені або за ініціативою Антимонопольного комітету Украйни, або за клопотанням зацікавлених осіб.

Результати. Вищезгадані зміни серйозно вплинуть на наявну систему захисту економічної конкуренції, зокрема:

- скасовується штраф за прострочення платежу, накладенийрішенням Антимонопольного комітету України про порушення законодавства про захист економічної конкуренції;

- член Антимонопольного комітету України, який проводив або організував розслідування, позбавляється права голосу у процесі прийняття рішень у відповідній справі;

- визначено порядок проведення слухань;

- для прачівників Антимонопольного комітету України передбачені самовідводи;

- змінюються підстави для набуття статусу третьої особи у справі;

- визначені й розширені права осіб, які беруть участь у справі.

Важливим зауваженням Закону України «Про внесення змін до деяких законів України щодо забезпечення принцииів процесуальної справедливості та підвищення ефективності проваджень у справах про порушення законодавства про захист економічної конкуренції» $\epsilon$ те, щзо особа, яка звільнена від відповідальності або суму штрафу якої було зменшено, все ще несе відповідальність за збиток, заподіяний іншим особам.

Висновки. У результаті передбачається, щуо Закон Украйни «Про внесення змін до деяких законів Украӥни щзодо забезпечення принципів процесуальної справедливості та підвищення ефективності проваджень у справах про порушення законодавства про захист економічної конкуренції» стане важливим кроком на шляху до підвищення ефективності розслідувань порушень законодавства про захист економічної конкурениії. Він також може розглядатися як наступний крок адаптації украйнського законодавства до законодавства Європейського Союзу.

Ключові слова: конкуренція, новела законодавства, Антимонопольний комітет України, розгляд справи, покарання, захист економічної конкуренції. 